\title{
A preliminary study on the diversity of invertebrates associated with Corallina officinalis Linnaeus in southern Istrian peninsula
}

\author{
Moira BURŠIĆ' ${ }^{1, *}$, Ljiljana IVEŠA², Andrej JAKLIN² and Milvana ARKO PIJEVAC ${ }^{3}$
}

\author{
${ }^{1}$ Department of Natural and Health Sciences, \\ Juraj Dobrila University of Pula, Zagrebačka 30, HR-52100 Pula, Croatia
}

${ }^{2}$ Center for Marine Research, Ruđer Bošković Institute, G. Paliaga 5, HR-52210 Rovinj, Croatia

${ }^{3}$ Natural History Museum Rijeka, Lorenzov prolaz, 1, HR-51000 Rijeka, Croatia

"Corresponding author, e-mail: moira.bursic@unipu.hr

\begin{abstract}
Red coralligenous algae Corallina officinalis provides shelter to many invertebrate species from wave actions, predation and desiccation stress in the intertidal area. Physical structure and complexity of the habitat have a major influence on biodiversity of this community. The aim of this preliminary study was to examine the diversity of invertebrate assemblages inside the red algae C. officinalis turf. Three sampling locations were chosen where algal cover range was above 90\%. On each location sampling was done quantitatively by scraping off within 3 replicate quadrats $20 \times 20$ $\mathrm{cm}$ in size. A total of 30,518 specimens were isolated from all sampling locations. The prevalent groups were amphipod crustaceans, polychaetes, bivalves and gastropods that made a total of $86 \%$ of all macrofaunal groups associated with algal turfs. The most abundant group were amphipods that made $42 \%$ of the total separated individual invertebrates. Our study demonstrated that C. officinalis is a very important habitat with high abundance and diversity of invertebrate assemblages.
\end{abstract}

Key words: invertebrates, Corallina officinalis, mapping, biodiversity, Istrian coast

\section{INTRODUCTION}

In many marine habitats macroalgae and other flora determine the physical structure of the environment and affect the composition of organisms and their interaction (MATIAS et al., 2007). This is also the case with the red incrusting algae Corallina officinalis Linneaus (GUIRY \& GUIRY, 2019) which modifies the environment with its characteristic structure. Thus, it provides shelter to many macrofaunal species from wave action, predation and dehydration in the intertidal zone (LIUZZI \& GAPPA, 2008). Many infaunal and epifaunal species seek shelter here during periods of unfavorable weather conditions (BERTNESS et al., 2006).

Physical structure and complexity of habitats have a major impact on the biodiversity of this community (KELAHER, 2002) and previous research around the world recorded up to 329,000 invertebrates per one square meter (BROWN \& TAYLOR, 1999; KELAHER et al., 2001; BUSSELL et al., 2007; LIUZZI \& GAPPA, 2008) which confirms that this algal turf is a very important habitat for preserving coastal biodiversity. Changes in structure and composition of macro- 
fauna associated with coralline algae have been explored worldwide (KELAHER, 2003; KELAHER et al., 2004; MATIAS et al., 2007; LIUZZI \& GAPPA, 2008; MATIAS et al., 2015; LAVENDER, et al., 2017). In the southwest Atlantic, changes in the structure of macrofaunal communities within the coralline algae settlements have been observed at local and regional scale since this type of habitat can occur along thousands of kilometers of shoreline. This broad distribution makes it suitable to analyze changes in benthic biodiversity and taxonomic turnover at different spatial scales. The study conducted by LIUZZI \& GAPPA (2008) concluded that changes in assemblage structure at the local scale were of a much smaller magnitude than those observed at regional scale and may be attributed to small differences in habitat topography, intertidal elevation, wave exposure, and distance to harbors or different sources of pollution. Invertebrates are considered very suitable organisms as indicators of natural and anthropogenic changes and there are various indices that use the ratio of sensitive and opportunistic species and groups in the assessment of the quality of coastal waters (DAUVIN \& RUELLET, 2007; BORJA et al., 2009; CABANA et al., 2013).

In the Mediterranean Sea Corallina officinalis is most commonly found in the intertidal zone, but it is also present at higher depths in subtidal area (BABBINI \& BRESSAN, 1997). The mapping carried out in the eastern Adriatic has shown that settlements of this coralline algae were registered across $13 \%$ of the surveyed coastline (NIKOLIĆ et al., 2013). Investigations in the area of the western coast of Istria recorded algae from the genus Corallina ( $C$. officinalis and $C$. elongata) at almost all research sites, with $C$. officinalis dominating in areas without anthropogenic influence (IVEŠA et al., 2009).

The lack of data about the abundance and composition of macrofauna associated with such widespread settlements of $C$. officinalis in Adriatic Sea determined the aim of this study, which was to examine the diversity of invertebrate assemblages inside the coralline turf and to acquire qualitative and quantitative data about invertebrates within its settlements in the northern Adriatic.

\section{MATERIAL AND METHODS}

\section{Study area}

The study area included the southern part of the Istrian peninsula (Adriatic Sea, Croatia) which is made of karstic coast and predominantly limestone in the intertidal area. Samples were taken where coastal slope was horizontal on sampling locations named Sac-

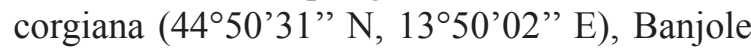

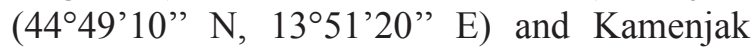
(4446'38" N, 135'20" E) (Fig. 1). All locations are semiexposed, particularly to southwest wind direction.

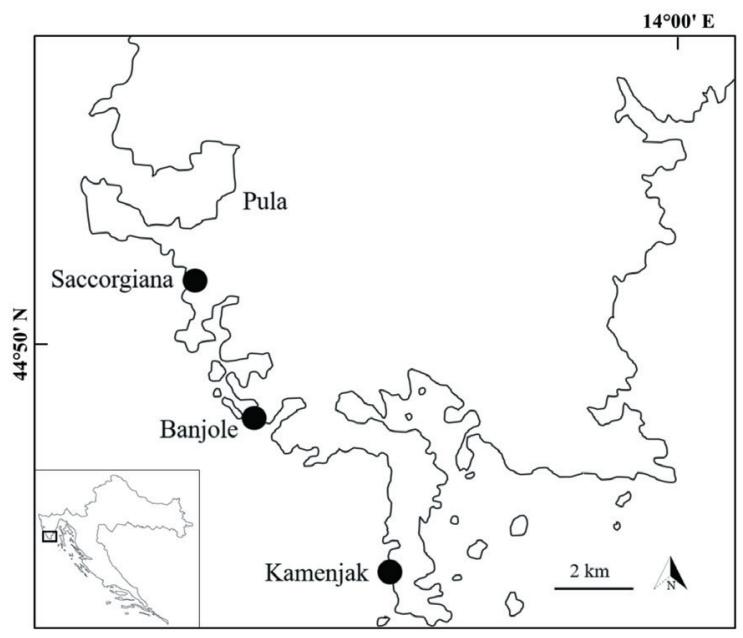

Fig. 1. Sampling locations at southern Istrian peninsula

\section{Sampling}

Sampling was performed from January till May 2016 at previously mentioned sampling locations. Sampling was done where the range of algal turf coverage was between $75 \%$ and $100 \%$ in a continuous belt about $50 \mathrm{~cm}$ wide, where the coastal slope was horizontal and where the exposure to wind and waves was quite high. On each location sampling was done quantitatively by scraping off within 3 replicate quadrats $20 \times 20 \mathrm{~cm}$ in size. Samples were taken with hammer and chisel and fixed in 4\% formalin. Sampling was done during low tide to minimize the loss of mobile invertebrates. In the laboratory samples, including $C$. officinalis, were rinsed through a sieve with $0.5 \mathrm{~mm}$ 
mesh size and stored in $70 \%$ ethanol for further processing. Macrofaunal organisms were sorted and counted under a binocular microscope and were identified to the lowest possible taxonomic level. After separation of all macrofaunal organisms, wet and dry weight of $C$. officinalis was also recorded. Algae were dried at $80^{\circ} \mathrm{C}$ for 24 hours. Mollusks were identified to the species level, whenever possible. Species were determined according to NORDSIEC, 1968, 1969; PARENZAN, 1970, 1974; SABELLI et al., 1990; POPPE \& GOTO, 1993; GIANUZZI-SAVELLI et al., 1996 and GOFAS et al., 2011a,b. For each taxa total number of individuals was recorded. Descriptive statistics and graphical representation of results was done using MS Excel considering all sampling locations as one. The nomenclature of the species was checked according to the World Register of Marine Species (WORMS, 2019).

\section{RESULTS}

Altogether 30,518 invertebrates were isolated from Corallina samples belonging to 24 different taxonomic groups whether is Phylum, Class, Order or Family. Average density value was 84,775 individuals per square meter (ind $\mathrm{m}^{-2}$ ). The highest value was recorded for Kamenjak with 116,250 ind $\mathrm{m}^{-2}$, while the average Corallina dry weight was lowest compared to other sampling locations (Table 1).

Table 1. Maximum density of individuals (ind $\mathrm{m}^{2}$ ) and average dry weight (dw) of $\mathrm{C}$. officinalis

\begin{tabular}{|l|c|c|}
\hline & max ind $\mathbf{~ m}^{-\mathbf{2}}$ & mean dw (g) \\
\hline Banjole & 81,625 & 197.92 \\
\hline Saccorgiana & 99,500 & 162.29 \\
\hline Kamenjak & 116,250 & 129.99 \\
\hline
\end{tabular}

The prevalent invertebrates were amphipod crustaceans, polychaetes, bivalves and gastropods that made a total of $86 \%$ of all individuals associated with algal turfs at all research locations. The most abundant group were amphipods with $42 \%$ of all separated invertebrates (Fig. 2) and they were by far the most dominant taxonomic group with more than 4,200 recorded individuals (Figure 3). Some taxonomic groups

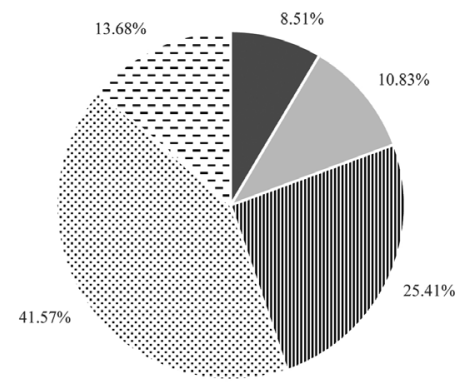

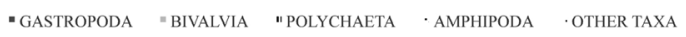

Fig 2. The most abundant taxonomic groups in $\mathrm{C}$. officinalis assemblages in studied area.

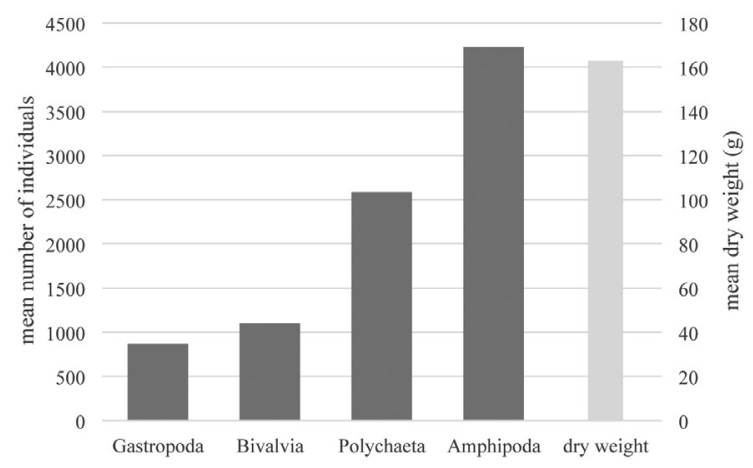

Fig. 3. Average number of individuals per each of the most abundant taxonomic groups in studied area

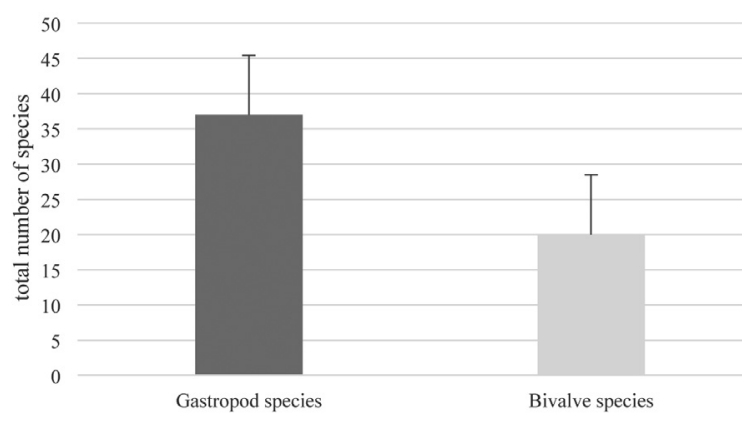

Fig. 4. Cumulative total value of gastropod and bivalve species in studied area

were represented with just a few individuals and had a total percentage of occurrence less than $0.1 \%$ (Table 2). These groups were Plathyhelminthes, Aplacopohora, Cumacea, Diptera, Anthozoa, Porifera and Echinoidea. A total of 37 gastropod and 20 bivalve species were recorded, but not all species were present at all sampling locations (Table $3 \& 4$; Fig. 4). Twelve of 37 
Table 2. Qualitative and quantitative composition of invertebrates

\begin{tabular}{lccccrrr}
\hline Taxonomic group & Banjole & Saccorgiana & Kamenjak & TOT & \% & mean & SD \\
\hline Platyhelminthes & 2 & 1 & 1 & 4 & 0.01 & 1.3 & 0.6 \\
Nemertea & 49 & 15 & 8 & 72 & 0.24 & 24.0 & 21.9 \\
Nematoda & 222 & 296 & 759 & 1277 & 4.18 & 425.7 & 291.0 \\
Sipuncula & 15 & 16 & 44 & 75 & 0.25 & 25.0 & 16.5 \\
Gastropoda & 358 & 1683 & 555 & 2596 & 8.51 & 865.3 & 714.9 \\
Bivalvia & 324 & 1589 & 1393 & 3306 & 10.83 & 1102.0 & 680.9 \\
Polyplacophora & 11 & 36 & 49 & 96 & 0.31 & 32.0 & 19.3 \\
Aplacophora & 0 & 1 & 0 & 1 & 0.00 & 0.3 & 0.6 \\
Polychaeta & 2407 & 3065 & 2282 & 7754 & 25.41 & 2584.7 & 420.6 \\
Decapoda & 14 & 23 & 34 & 71 & 0.23 & 23.7 & 10.0 \\
Cumacea & 13 & 4 & 1 & 18 & 0.06 & 6.0 & 6.2 \\
Tanaidacea & 391 & 148 & 172 & 711 & 2.33 & 237.0 & 133.9 \\
Isopoda & 150 & 313 & 15 & 478 & 1.57 & 159.3 & 149.2 \\
Amphipoda & 4606 & 2515 & 5564 & 12685 & 41.57 & 4228.3 & 1559.2 \\
Caprellidae & 4 & 5 & 345 & 354 & 1.16 & 118.0 & 196.6 \\
Copepoda & 0 & 12 & 64 & 76 & 0.25 & 25.3 & 34.0 \\
Crustacea varia & 3 & 0 & 0 & 3 & 0.01 & 1.0 & 1.7 \\
Pantopoda & 234 & 199 & 11 & 444 & 1.45 & 148.0 & 119.9 \\
Acari & 35 & 198 & 15 & 248 & 0.81 & 82.7 & 100.4 \\
Diptera & 0 & 0 & 14 & 14 & 0.05 & 4.7 & 8.1 \\
Anthozoa & 1 & 0 & 0 & 1 & 0.00 & 0.3 & 0.6 \\
Porifera & 1 & 0 & 0 & 1 & 0.00 & 0.3 & 0.6 \\
Echinoidea & 1 & 2 & 0 & 3 & 0.01 & 1.0 & 1.0 \\
Ophiuroidea & 66 & 64 & 100 & 230 & 0.75 & 76.7 & 20.2 \\
\hline & & & & & & &
\end{tabular}

Table 3. Qualitative and quantitative composition of gastropods

Species
Alvania discors (T. Allan, 1818)
Alvania parvula (Jeffreys, 1884)
Alvania scabra (Philippi, 1844)
Alvania sp. juv.
Bittium reticulatum (da Costa, 1778)
Brachystomia eulimoides (Hanley, 1844)
Cerithium vulgatum Bruguière, 1792
Cerithiopsis tubercularis (Montagu, 1803)
Cingula trifasciata (J. Adams, 1800)
Clanculus cruciatus (Linnaeus, 1758)
Crisilla innominata (R. B. Watson, 1897)
Columbella rustica (Linnaeus, 1758)
Eatonina cossurae (Calcara, 1841)
Epitonium clathratulum (Kanmacher, 1798)
Fissurellidae indet. juv

\begin{tabular}{|c|c|c|c|c|c|c|}
\hline Banjole & Saccorgiana & Kamenjak & TOT & \% & mean & SD \\
0 & 5 & 1 & 6 & 0.23 & 2.0 & 2.6 \\
2 & 0 & 0 & 2 & 0.08 & 0.7 & 1.2 \\
0 & 4 & 0 & 4 & 0.15 & 1.3 & 2.3 \\
0 & 0 & 2 & 2 & 0.08 & 0.7 & 1.2 \\
151 & 1209 & 329 & 1689 & 65.06 & 563.0 & 566.5 \\
3 & 0 & 0 & 3 & 0.12 & 1.0 & 1.7 \\
0 & 2 & 0 & 2 & 0.08 & 0.7 & 1.2 \\
1 & 0 & 0 & 1 & 0.04 & 0.3 & 0.6 \\
1 & 3 & 0 & 4 & 0.15 & 1.3 & 1.5 \\
0 & 1 & 1 & 2 & 0.08 & 0.7 & 0.6 \\
8 & 75 & 15 & 98 & 3.78 & 32.7 & 36.8 \\
1 & 1 & 10 & 12 & 0.46 & 4.0 & 5.2 \\
9 & 136 & 0 & 145 & 5.59 & 48.3 & 76.1 \\
2 & 0 & 0 & 2 & 0.08 & 0.7 & 1.2 \\
1 & 2 & 3 & 6 & 0.23 & 2.0 & 1.0
\end{tabular}


Gibbula sp. juv.

Hexaplex trunculus (Linnaeus, 1758)

Jujubinus striatus (Linnaeus, 1758)

Megastomia winfriedi Peñas \& Rolán, 1999

Melarhaphe neritoides (Linnaeus, 1758)

Monophorus perversus (Linnaeus, 1758)

Muricopsis cristata (Brocchi, 1814)

Ocenebra edwardsii (Payraudeau, 1826)

Patella cf. caerulea juv. Linnaeus, 1758

Pusia ebenus (Lamarck, 1811)

Pusia tricolor (Gmelin, 1791)

Pusillina philippi (Aradas \& Maggiore, 1844)

Scissurella costata d'Orbigny, 1824

Setia fusca (Philippi, 1841)

Setia maculata (Monterosato, 1869)

Siphonaria cf. pectinata (Linnaeus, 1758) juv.

Spiralinella incerta (Milaschewich, 1916)

Steromphala adriatica (Philippi, 1844) juv.

Tritia elongata

(Bucquoy, Dautzenberg \& Dollfus, 1882)

Tritia incrassata (Strøm, 1768)

Tritonia manicata Deshayes, 1853

Vitreolina antiflexa (Monterosato, 1884)

\begin{tabular}{|c|c|c|c|c|c|c|}
6 & 0 & 0 & 6 & 0.23 & 2.0 & 3.5 \\
0 & 1 & 2 & 3 & 0.12 & 1.0 & 1.0 \\
2 & 1 & 0 & 3 & 0.12 & 1.0 & 1.0 \\
0 & 14 & 0 & 14 & 0.54 & 4.7 & 8.1 \\
0 & 2 & 0 & 2 & 0.08 & 0.7 & 1.2 \\
3 & 2 & 0 & 5 & 0.19 & 1.7 & 1.5 \\
0 & 5 & 4 & 9 & 0.35 & 3.0 & 2.6 \\
1 & 0 & 0 & 1 & 0.04 & 0.3 & 0.6 \\
2 & 0 & 0 & 2 & 0.08 & 0.7 & 1.2 \\
0 & 1 & 1 & 2 & 0.08 & 0.7 & 0.6 \\
0 & 1 & 0 & 1 & 0.04 & 0.3 & 0.6 \\
3 & 0 & 0 & 3 & 0.12 & 1.0 & 1.7 \\
84 & 103 & 65 & 252 & 9.71 & 84.0 & 19.0 \\
0 & 6 & 0 & 6 & 0.23 & 2.0 & 3.5 \\
68 & 90 & 113 & 271 & 10.44 & 90.3 & 22.5 \\
3 & 1 & 2 & 6 & 0.23 & 2.0 & 1.0 \\
1 & 8 & 2 & 11 & 0.42 & 3.7 & 3.8 \\
1 & 2 & 1 & 4 & 0.15 & 1.3 & 0.6 \\
0 & 1 & 0 & 1 & 0.04 & 0.3 & 0.6 \\
2 & 0 & 0 & 2 & 0.08 & 0.7 & 1.2 \\
2 & 5 & 2 & 9 & 0.35 & 3.0 & 1.7 \\
1 & 2 & 2 & 5 & 0.19 & 1.7 & 0.6 \\
\hline
\end{tabular}

Table 4. Qualitative and quantitative composition of bivalves

\begin{tabular}{|lccccccc|}
\hline Species & Banjole & Saccorgiana & Kamenjak & TOT & \% & mean & SD \\
Aequipecten opercularis (Linnaeus, 1758) & 1 & 1 & 0 & 2 & 0.06 & 0.7 & 0.6 \\
Arca noae Linnaeus, 1758 & 7 & 8 & 2 & 17 & 0.51 & 5.7 & 3.2 \\
Arca tetragona Poli, 1795 & 2 & 8 & 0 & 10 & 0.30 & 3.3 & 4.2 \\
Arca sp. & 3 & 4 & 0 & 7 & 0.21 & 2.3 & 2.1 \\
Cardiadae indet. & 27 & 131 & 52 & 210 & 6.35 & 70.0 & 54.3 \\
Cardita calyculata (Linnaeus, 1758) & 0 & 1 & 0 & 1 & 0.03 & 0.3 & 0.6 \\
Ctena decussata (O. G. Costa, 1829) & 1 & 0 & 0 & 1 & 0.03 & 0.3 & 0.6 \\
Flexopecten glaber (Linnaeus, 1758) & 0 & 1 & 0 & 1 & 0.03 & 0.3 & 0.6 \\
Hiatella sp. & 0 & 15 & 55 & 70 & 2.12 & 23.3 & 28.4 \\
Irus irus (Linnaeus, 1758) & 0 & 1 & 0 & 1 & 0.03 & 0.3 & 0.6 \\
Lasaea sp. & 0 & 1 & 0 & 1 & 0.03 & 0.3 & 0.6 \\
Lima lima (Linnaeus, 1758) & 2 & 0 & 0 & 2 & 0.06 & 0.7 & 1.2 \\
Lima sp. & 0 & 2 & 0 & 2 & 0.06 & 0.7 & 1.2 \\
Mimachlamys varia (Linnaeus, 1758) & 3 & 0 & 0 & 3 & 0.09 & 1.0 & 1.7 \\
Modiolus barbatus (Linnaeus, 1758) & 16 & 31 & 10 & 57 & 1.72 & 19.0 & 10.8 \\
Musculus costulatus (Risso, 1826) & 73 & 161 & 323 & 557 & 16.85 & 185.7 & 126.8 \\
Mytilus galloprovincialis Lamarck, 1819 & 0 & 0 & 5 & 5 & 0.15 & 1.7 & 2.9 \\
Mytilaster sp. & 187 & 1218 & 942 & 2347 & 70.99 & 782.3 & 533.7 \\
Pododesmus patelliformis (Linnaeus, 1761) & 2 & 0 & 0 & 2 & 0.06 & 0.7 & 1.2 \\
Veneridae indet. & 0 & 6 & 4 & 10 & 0.30 & 3.3 & 3.1 \\
\hline
\end{tabular}


(32\%) gastropod species were present at all sampling locations, while for bivalves 5 of 20 $(25 \%)$ species were common for all locations. The structure of the total bivalve fauna was determined by the distinctive dominance of the family Mytilidae (genus Mytilaster and Musculus costulatus), whereas the total gastropod fauna was determined by Bittium reticulatum, Scissurella costata and Setia maculata as the most abundant species. The lowest abundance of bivalves and gastropods were recorded for Banjole, while Kamenjak, as the location with higher abundance of invertebrates, had the lowest number of bivalve and gastropod species recorded.

\section{DISCUSSION}

High numbers of invertebrates were recorded in many worldwide studies of macrofauna associated with Corallina officinalis turfs. In the United Kingdom, it was estimated that up to 329,000 individual invertebrates can be found per one square meter (BUSSELL et al., 2007). Research in New Zealand has reached 80,000 ind $\mathrm{m}^{-2}$ (BERTHELSEN et al., 2015b), in South America up to 304,000 ind $\mathrm{m}^{-2}$ (LIUZZI \& GAPPA, 2008), and in Australia up to 250,000 ind $\mathrm{m}^{-2}$ (KELAHER et al., 2001). In this preliminary study the average number of invertebrates per $\mathrm{m}^{2}$ was close to 85,000 , ranging from approximately 64,000 to more than 116,000 ind $\mathrm{m}^{-2}$ (Table 5).

Our study recorded 59 molluscan taxa which is the second highest number of recorded molluscan taxa in similar prior studies, comparing to the highest number of 82 taxa recorded in a study conducted in Australia by KELAHER et al. (2001) (Table 5). If this comparison is done only for recorded bivalve taxa, our study shows the highest number of 20 recorded bivalve taxa followed by 16 taxa recorded in Argentina by KELAHER et al. (2007a). Comparing the species list of mollusks there are 11 genera that are common for present and previous studies: Cingula (DOMMASNES, 1969), Eatonina (KELAHER, 2003), Fisurella, Hiatella, Siphonaria, (KELAHER et al., 2007a; KELAHER et al., 2007b), Lasaea (AKIOKA et al.,1999; KELAHER et al., 2007a; KELAHER et al., 2007b), Modiolus (AKIOKA et al.,1999), Muricopsis and Pusilina (BERTHELSEN et al., 2015b), Musculus (KELAHER et al., 2007a) and Mytilus (AKIOKA et al., 1999; KELAHER et al., 2007a). These are all studies conducted in different regions than the Adriatic Sea, in Australia, New Zealand, Chile, Argentina, Japan and Norway, so a difference in species composition is to be expected.

LIUZZI \& GAPPA (2008) pointed out in their study a lower diversity of macrofaunal organisms in habitats where the algae density is higher, which is explained by the extremely high abundance of juvenile mussels from the Mytilidae family. Species belonging to Mytilidae family (Modiolus barbatus, Musculus costulatus, Mytilus galloprovincialis and Mytilaster sp.) showed high abundance even in our study and made $90 \%$ of the total number of isolated bivalves. Looking at each sampling location separately, Kamenjak had the highest percentage of species belonging to Mytilidae family and the lowest number of bivalve and gastropod species recorded which corresponds to LIUZZI \& GAPPA (2008) conclusions.

Prior analyses of the turf forming algal biomass effect on the invertebrate species richness showed a positive relationship between the number of species of invertebrates and the biomass of algae (MATIAS et al., 2015). Another positive effect on the overall diversity of macrofaunal assemblages of this habitat was recorded, which is the fact that turf forming algae retain a larger amount of sediment that serves as a secondary habitat for many macrofaunal species and meiofauna (AIROLDI \& CINELLI, 1997).

The effects of changes in the habitat structure on the number and distribution of species within were also previously studied. MATIAS et al. (2011) concluded that reducing the diversity of habitats would have adverse effects on the diversity of taxonomic groups, as the habitat structure itself greatly affects the spatial distribution of species. Therefore, given the complexity of the algae's habitat, the composition of macrofaunal species varies. Within our preliminary study samples were taken during the period when algal density was at its peak, as the focus was to determine possible maximum diversity of invertebrates 
Table 5. Comparison of the number of taxa in coralline turf on different locations throughout the world.

\begin{tabular}{|c|c|c|c|c|c|c|}
\hline Location & $\begin{array}{l}\text { No. of } \\
\text { molluscan } \\
\operatorname{taxa}\end{array}$ & $\begin{array}{l}\text { No. of } \\
\text { gastropod } \\
\text { taxa }\end{array}$ & $\begin{array}{c}\text { No. of } \\
\text { bivalve } \\
\text { taxa }\end{array}$ & $\begin{array}{l}\text { No. of } \\
\text { all taxa }\end{array}$ & $\begin{array}{c}\text { Max. } \\
\text { density } \\
\left(\text { ind } \mathrm{m}^{-2} \text { ) }\right.\end{array}$ & References \\
\hline Croatia & 59 & 37 & 20 & 79 & 116,250 & Present study \\
\hline Norway & 26 & 18 & 8 & 70 & l & DOMMASNES, 1969 \\
\hline Japan & 22 & 15 & 6 & 91 & / & AKIOKA et al., 1999 \\
\hline Australia (South-Eastern) & 82 & 65 & 11 & 147 & 250,000 & KELAHER et al., 2001 \\
\hline Ireland (West Coast) & 24 & 17 & 6 & 24 & l & \multirow{3}{*}{ KELAHER et al., 2004} \\
\hline Chile (Central) & 27 & 15 & 7 & 27 & / & \\
\hline Australia (East Coast) & 58 & 46 & 6 & 58 & / & \\
\hline Chile (Northern) & 35 & 23 & 8 & 94 & / & $\begin{array}{l}\text { KELAHER \& } \\
\text { CASTILLA, } 2005\end{array}$ \\
\hline Argentina (Southern) & 38 & 18 & 16 & 38 & 77,000 & KELAHER et al. 2007a \\
\hline Chile (Central) & 30 & 19 & 8 & 30 & / & KELAHER et al., 2007b \\
\hline Wales & 27 & / & / & 123 & 329,000 & BUSSELL et al., 2007 \\
\hline Argentina (North \& Central) & 21 & / & / & 118 & 304,400 & LIUZZI \& GAPPA, 2008 \\
\hline New Zealand & 46 & 38 & 2 & 118 & 53,643 & $\begin{array}{l}\text { BERTHELSEN et al., } \\
\text { 2015a }\end{array}$ \\
\hline New Zealand & / & 48 & / & 129 & 80,000 & $\begin{array}{l}\text { BERTHELSEN et al., } \\
\text { 2015b }\end{array}$ \\
\hline
\end{tabular}

within this alga, so a seasonal dynamic should be investigated to have a more precise conclusion about the abundance trends and the effect of algal structure on the macrofaunal composition.

\section{CONCLUSIONS}

These preliminary results showed that the diversity of invertebrates associated with Corallina officinalis in northern Adriatic Sea is high and comparable to the numbers recorded in other studies that were conducted throughout the world. Corallina as a habitat has great potential for investigating different anthropogenic impacts as many indicator invertebrate species are commonly found within its settlements. Along with the seasonal dynamic of macrofaunal composition, future studies will examine how the anthropogenic influence is affecting macrobenthic communities associated with $C$. officinalis, an important coastal habitat with abundant and diverse macrofaunal assemblages.

\section{ACKNOWLEDGEMENTS}

The authors are grateful to the anonymous reviewers for their suggestions and comments, which allowed significant improvement of the manuscript.

\section{REFERENCES}

AIROLDI, L., \& F. CINELLI. 1997. Effects of sedimentation on subtidal macroalgal assemblages: an experimental study from a Mediterranean rocky shore. Journal of Experimental Marine Biology and Ecology, 215(2): 269-288.

AKIOKA, H., BABA, M., MASAKI, T. \& W. JOHANSEN. 1999. Rocky shore turfs dominated by Corallina (Corallinales, Rhodophtya) in Northern Japan. Phycological Research, 47: 199-206. 
BABBINI, L. \& G. BRESSAN. 1997. Recensement de Corallinacées de la Mer Méditerranée et considérations phytogéographiques (A revision of the inventory of corallinales of the Mediterranean Sea and phytogeographical conclusions from the data). Bibliotheca Phycologica, 103: p. 421.

BERTHELSEN, A.K., HEWITT, J.E., \& R.B. TAYLOR. 2015a. Biological traits and taxonomic composition of invertebrate assemblages associated with coralline turf along an environmental gradient. Marine Ecology Progress Series, 530: 15-27.

BERTHELSEN, A.K., HEWITT, J.E., \& R.B. TAYLOR, 2015b. Coralline turf-associated fauna are affected more by spatial variability than by host species identity. Marine Biodiversity, 45(4): 689-699.

BERTNESS, M.D., CRAIN, C.M., SILLIMAN, B.R., BAZTERRICA, M.C., REYNA, M.V., HILDAGO, F., \& J.K. FARINA. 2006. The community structure of western Atlantic Patagonian rocky shores. Ecological Monographs, 76(3): 439-460.

BORJA, A., A. MILES, A. OCCHIPINTI-AMBROGI, \& T. BERG. 2009. Current status of macroinvertebrate methods used for assessing the quality of European marine waters: implementing the Water Framework Directive. Hydrobiologia, 633(1): 181-196.

BROWN, P.J. \& R.B. TAYLOR. 1999. Effects of trampling by humans on animals inhabiting coralline algal turf in the rocky intertidal. Journal of Experimental Marine Biology and Ecology, 235(1): 45-53.

BUSSELL, J.A., I.A.N. LUCAS \& R. SEED. 2007. Patterns in the invertebrate assemblage associated with Corallina officinalis in tide pools. Journal of the Marine Biological Association of the UK, 87(02): 383-388.

CABANA, D., K. SIGALA, A. NICOLAIDOU \& S REIZOPOULOU. 2013. Towards the implementation of the Water Framework Directive in Mediterranean transitional waters: the use of macroinvertebrates as biological quality elements. Advances in Oceanography and Limnology, 4(2): 212-240.

DAUVIN, J.C. \& T. RUELLET. 2007. Polychaete/ amphipod ratio revisited. Marine Pollution Bulletin, 55(1-6): 215-224.
DOMMASNES, A. 1969. On the fauna of Corallina officinalis L. in Western Norway. Sarsia 38: 71-86.

GIANUZZI-SAVELLI, R., F. PUSATERI, A. PALMERI \& C. EBREO. 1996. Atlante delle conchiglie marine del Mediterraneo (Atlas of the Mediterranean SeaShells). La Conchiglia, Roma, $258 \mathrm{pp}$.

GOFAS, S., D. MORENO \& C. SALAS. (Editors). 2011a. Moluscos marinos de Andalucía. Vol. I (Marine Mollusks from Andalusia. Vol. I). Universidad de Málaga, Málaga, 342 pp.

GOFAS, S., D. MORENO \& C. SALAS. (Editors). 2011b. Moluscos marinos de Andalucía. Vol. II (Marine Mollusks from Andalusia. Vol. I). Universidad de Málaga, Málaga, 455 pp.

GUIRY, M.D. \& G.M. GUIRY. 2019. AlgaeBase. Worldwide electronic publication, National University of Ireland, Galway. https://www. algaebase.org

IVEŠA, L., LYONS, D.M. \& M. DEVESCOVI. 2009. Assessment of the ecological status of northeastern Adriatic coastal waters (Istria, Croatia) using macroalgal assemblages for the European Union Water Framework Directive. Aquatic Conservation: Marine and Freshwater Ecosystems, 19(1): 14-23.

KELAHER, B.P. 2002. Influence of physical characteristics of coralline turf on associated macrofaunal assemblages. Marine Ecology Progress Series, 232: 141-148.

KELAHER, B.P. 2003. Changes in habitat complexity negatively affect diverse gastropod assemblages in coralline algal turf. Oecologia, 135(3): 431-441.

KELAHER, B.P., M.G. CHAPMAN \& A.J. UNDERWOOD. 2001. Spatial patterns of diverse macrofaunal assemblages in coralline turf and their associations with environmental variables. Journal of the Marine Biological Association of the UK, 81(06): 917-930.

KELAHER, B.P., J.C. CASTILLA \& R. SEED. 2004. Intercontinental test of generality for spatial patterns among diverse molluscan assemblages in coralline algal turf. Marine Ecology Progress Series, 271: 221-231.

KELAHER B.P. \& J.C. CASTILLA. 2005. Habitat characteristics influence macrofaunal com- 
munities in coralline turf more than mesoscale coastal upwelling on the coast of Northern Chile. Estuarine Coastal and Shelf Science, 63: 155-165.

KELAHER, B.P., J.C. CASTILLA, L. PRADO, P. YORK, E. SCHWINDT \& A. BORTOLUS. 2007a. Spatial variation in molluscan assemblages from coralline turfs of Argentinean Patagonia. Journal of Molluscan Studies 73: 139-146.

KELAHER, B.P., J.C. CASTILLA \& L. PRADO 2007b. Is there redundancy in bioengineering for molluscan assemblages on the rocky shores of central Chile? Revista Chilena de Historia Natural, 80(2): 173-186.

LAVENDER, J.T., K.A. DAFFORN, M.J. BISHOP, \& E.L. JOHNSTON. 2017. Small-scale habitat complexity of artificial turf influences the development of associated invertebrate assemblages. Journal of Experimental Marine Biology and Ecology, 492: 105-112.

LIUZZI, M. \& J. LÓPEZ GAPPA. 2008. Macrofaunal assemblages associated with coralline turf: species turnover and changes in structure at different spatial scales. Marine Ecology Progress Series, 363: 147-156.

MATIAS, M.G., A.J. UNDERWOOD \& R.A. COLEMAN. 2007. Interactions of components of habitats alter composition and variability of assemblages. Journal of Animal Ecology, 76(5): 986-994.

MATIAS, M.G., A.J. UNDERWOOD, D.F. HOCHULI \& R.A. COLEMAN. 2011. Habitat identity influences species-area relationships in heterogeneous habitats. Marine Ecology Progress Series, 437: 135-145.

MATIAS, M.G., F. ARENAS, M. RUBAL \& I.S. PINTO. 2015. Macroalgal Composition Determines the Structure of Benthic Assemblages Colonizing Fragmented Habitats. PLoS ONE,
10(11), e0142289. https://doi.org/10.1371/journal.pone. 0142289

NIKOLIĆ, V., A. ŽULJEVIĆ, L. MANGIALAJO, B. ANTOLIĆ, G. KUŠPILIĆ \& E. BALLESTEROS. 2013. Cartography of littoral rocky-shore communities (CARLIT) as a tool for ecological quality assessment of coastal waters in the Eastern Adriatic Sea. Ecological Indicators, 34: 87-93.

NORDSIECK, F. 1968. Die europäischen MeeresGehäuseschnecken (Prosobranchia) (The European Sea Snails (Prosobranchia)). Gustav Fischer Verlag, Stuttgart, 273 pp.

NORDSIECK, F. 1969. Die europäischen Meeresmuscheln (Bivalvia) (The European Seashells (Bivalvia)). Gustav Fisher Verlag, Stuttgart, $256 \mathrm{pp}$.

PARENZAN, P. 1970. Carta d'identità delle conchiglie del Mediterraneo. Vol. I. Gasteropodi (Identity Card of Mediterranean Seashells. Vol. I. Gastropods). Bios Taras, Taranto, 283 pp.

PARENZAN, P. 1974. Carta d'identità delle conchiglie del Mediterraneo. Vol. II. Bivalvi, prima parte (Identity Card of Mediterranean Seashells. Vol. II. Bivalves, part one). Bios Taras, Taranto, $277 \mathrm{pp}$.

POPPE, G.T. \& Y. GOTO. 1993. European Seashells. Vol. II (Scaphopoda, Bivalvia, Cephalopoda). Verlag Christa Hemmen, Wiesbaden, 221 pp.

SABELLI, B., GIANUZZI-SAVELLI, R. \& D. BEDULLI. 1990. Catalogo annotato dei molluschi marini del Mediterraneo. Vol. I (Annotated Checklist of Mediterranean Marine Mollusks. Vol. I). Libreria Naturalistica Bolognese, Bologna, $348 \mathrm{pp}$.

WoRMS, 2019. World Register of Marine Species. http://www.marinespecies.org 


\title{
Preliminarno istraživanje raznolikosti bezkralježnjaka unutar naselja alge Corallina officinalis na području južne Istre
}

\author{
Moira BURŠIĆ, Ljiljana IVEŠA, Andrej JAKLIN i Milvana ARKO PIJEVAC
}

Kontakt e-pošta: moira.bursic@unipu.hr

\begin{abstract}
SAŽETAK
Crvena inkrustirajuća alga Corallina officinalis pruža zaklon mnogim beskralješnjacima u području mediolitorala od djelovanja valova, predacije i isušivanja. Karakteristična struktura i složenost staništa imaju veliki utjecaj na bioraznolikost ove zajednice. Cilj ovog rada bio je istražiti raznolikost faune beskralješnjaka unutar naselja crvene alge $C$. officinalis. Tri lokacije uzorkovanja odabrane su na području gdje je pokrivenost algom bila veća od 90\%. Na svakoj lokaciji uzorkovanje je provedeno kvantitativno u 3 replikata, struganjem unutar kvadrata veličine $20 \times 20 \mathrm{~cm}$. Ukupno je izolirano 30.518 jedinki, a dominantne skupine bile su amfipodni rakovi, mnogočetinaši, školjkaši i puževi.

Ovi taksoni su činili ukupno 86\% svih beskralješnjaka pronađenih unutar staništa alge. Najbrojnija skupina su amfipodni rakovi koji su činili 42\% ukupnih izoliranih beskralježnjaka. Naše je istraživanje pokazalo da je naselje alge $C$. officinalis vrlo važno stanište s visokom brojnošću i raznolikošću beskralješnjaka.
\end{abstract}

Ključne riječi: beskralješnjaci, Corallina officinalis, kartiranje, bioraznolikost, obala Istre 